\title{
The immunohistopathological features of prurigo Hebra
}

\author{
Siti Aisah Boediardja,* Achmad Tjarta,** Santoso Cornain,** Unandar Budimulja,* Adhi Djuanda, *Endang.S. \\ Roostini, ${ }^{* *}$ Meny Hartati**
}

\begin{abstract}
Abstrak
Sampai saat ini mekanisme prurigo Hebra (PH) belum diketahui secara pasti. Namun, berdasarkan adanya riwayat dalam keluarga yang menderita penyakit serupa serta riwayat alergi terhadap gigitan nyamuk, besar kemungkinan mekanismenya merupakan mekanisme hipersensitivitas. Penelitian ini bertujuan mengevaluasi gambaran imunohistopatologik PH khususnya sebukan sel inflamasi umum dan spesifik pada lesi awal dan lesi kronik. Penelitian dilakukan terhadap 50 spesimen yang berasal dari biopsi lesi awal dan 50 lesi lanjut. Setelah diproses sediaan tersebut diwarnakan dengan HE dan imunoperoksidase (IP) menggunakan antibodi monoklonal terhadap sel inflamasi spesifik, yaitu sel B, sel $T$, sel T-helper $C D 4+($ sel $C D 4+)$, sel $T$-supresor CD8+ (sel CD8+). sel Langerhans, dan sel penyaji antigen (SPA) yang mengekspresikan HLA-DR (SPA/HLA-DR). Pewarnaan HE pada lesi lanjut menunjukkan sebukan sel radang campuran yang lebih banyak dibandingkan dengan lesi awal. Pada lesi awal jumlah sebukan sel polimorfonuklear hanya sedikit, sedangkan eosinofil sangat banyak tetapi sel mas tidak ditemukan. Hasil pewarnaan IP memperlihatkan sebukan sel radang terdiri atas sel T: CD4+ dan sel CD8+, sel Langerhans, dan SPA/HLA-DR jumlahnya pada lesi lanjut lebih banyak daripada lesi awal, tetapi perbedaan ini tidak bermakna ( $p>0.05$ ), kecuali CD4+. Pada sediaan lesi awal maupun lesi lanjut sebukan sel CD4+ lebih banyak jumlahnya daripada sel CD8+ dengan ratio 3:1 dan 2:1. Sel B yang normalnya tidak dijumpai di kulit, ditemukan dalam jumlah sedikit, serta tidak berhubungan dengan banyaknya eosinofil dan sel T. Jumlah sel Langerhans (SL) di epidermis pada lesi lanjut lebih banyak daripada awal. Secara statistik ditemukan korelasi kuat (0.39) antara jumlah sel $T$ dan SPA/HLADR. berdasarkan hal tersebut dapat disimpulkan bahwa pasien prurigo selalu terpajan faktor ekstrinsik. Analsis menunjukkan pada PPH yang memiliki HLA-A10 atau HLA-A10-split, makin berat penyakitnya makin banyak jumlah sebukan eosinofil $\left(X^{2}\right.$ for trend $<0.05$ ). Sel radang yang didapatkan pada penelitian ini memperlihatkan bahwa mekanisme terjadinya prurigo Hebra sesuai reaksi hipersensitivitas campuran tipe I dan tipe IV. (Med J Indones 2001; 10:1-15)
\end{abstract}

\begin{abstract}
Until now the pathologic mechanisms of prurigo Hebra $(P H)$ is still understood. Earlier study the genetic inheritance of PH showed the multifactorial pattern. Considering the genetic inheritance and the existence of allergic reaction to insects bite in all patients, might be the mechanisms followed hypersensitivity reactions. The purpose of this study is to evaluate the general and specific local inflammatory features of early and late lesions of prurigo Hebra (PH). Fifty biopsy specimens of early and late lesions of prurigo Hebra patients were processed with haematoxylin-eosin $(H E)$ and immunoperoxyde (IP) staining using monoclonal antibodies against specific inflammatory cells namely $B$ cells, $T$ cells, helper $T(C D 4+)$ cells, supressor $T(C D 8+)$ cells, Langerhans cells, and antigen presenting cells (APC) that expressed HLA-DR antigen. HE-stained specimens: In early lesions, PMN cells were few, while eosinophils were present in great quantity and independent of mast cells and plasma cells; this feature was similar to that of insect bite reaction. IP-stained specimens: In late lesions, the amounts of lympho-histiocytic infiltration consisting of $T$ cells, CD8+cells, HLA-DR-expressing APCs were greater than those of early lesions, although it was not statistically significant. An exception was for the CD4+ cells, whose number in early lesions was significantly higher. The ratio of CD4+ to CD8+ in early lesions was higher than in late lesions (3/I: 2/I). This suggested that CD4+ cells were predominant. $B$ cells, which were normally absent, appeared in small quantity in both early and late lesions. The presence of $B$ cells was not statistically correlated with $T$ cells or eosinophils. The number of Langerhans cells in late lesions was higher than in early lesions. There was a strong correlation ( $r=0.39)$ between T cells and HLA$D R$-expressing antigen-presenting cells (APCs/HLA-DR). Those cells found in great quantity suggested that PH patients usually expose to extrinsic factors. In some cases with severe condition, the presence of eosinophils was more profound and was statistically significant. It is conclude that immunohistopathological mechanisms of PH follow the mixed types (one and IV) hypersensitivity reaction. (Med J Indones 2001; 10:1-15)
\end{abstract}

Keywords: Prurigo Hebra, eosinophils, CD4+cells, mixed (I and IV) types of hypersensitivity.

* Department of Dermato-venereology, Faculty of Medicine, University of Indonesia, Jakarta, Indonesia

** Department of Pathology, Faculty of Medicine, University of Indonesia
Prurigo Hebra is a chronic, inflammatory skin disease which mostly affects young children at 5-18 and even to people age over 40 years. It has been acknowledged since Ferdinand von Hebra (1816-1841) explained the 
disease in Vienna, Austria. Its clinical manifestations, itching, prurigo papules, hyperpigmentation and hyperkeratotic skin, greatly inhibit patient's activity and aesthetic performance. ${ }^{1-6}$ In Indonesia. prurigo Hebra cases are very common. even in a referral hospital like Dr. Cipto Mangunkusumo General Hospital, Jakarta. ${ }^{7.8}$

The diagnosis is not especially difficult; the disease is easily recognized by its specific locations: the extensor surface of lower and upper extremities, face. buttocks and abdomen. Patients generally complain of severe itching. The manifestation is limited to the skin, appearing as polymorphic lesions such as erythema and dome-shaped papules with tiny vesicle on its top. The vesicles are immediately ruptured by scratching then the lesions become eroded and excoriated. ${ }^{1-6}$ Agents of hypersensitivity, such as bed bugs, ants, mosquitoes, and certain drugs and foods, as well as bad hygiene and poor nutrition, are claimed as the factors that trigger or influence the development of the disease, ${ }^{9,10}$

Until now, the mechanism of the disease has not been fully understood. Occampo 1975, Australian, found that the histopathological specimens stained with $\mathrm{HE}$ of early infantile prurigo Hebra lesions showed acute inflammatory infiltration consisting of polymorphonuclear cells and eosinophils. This feature was similar to that of insect bite reaction. ${ }^{10}$ On the other hand, Boediardja, 1987, Indonesian, found that the histopathological examination on 159 HE biopsy specimens of chronic prurigo Hebra lesions showed chronic inflammatory infiltration predominated by lymphocytes, histiocytes and eosinophils. This finding could not be concluded wether the underlying mechanism was a general or specific immunological reaction, even though the presence of eosinophils suggested immediate (type I) hypersensitivity reaction. Boediardja, 1987, also found an increase of total IgE levels in $50 \%$ of 159 patients. ${ }^{9}$ Occampo, 1975, confirmed the hypersensitivity to insect bite in prurigo Hebra, his study on 100 infantile prurigo cases found positive prick test reaction to insect allergens. ${ }^{10}$

The aim of this study is to identify the local immunologic mechanism of the disease using histopathological examination with $\mathrm{HE}$ and IP stainings.

\section{METHODS}

A descriptive-analytic study was designed to compare the inflammatory cells infiltration in the early (A) and late (chronic) lesions (B). Fifty cases of prurigo Hebra were included in the study. Skin biopsy was taken from an early lesion (red papule that appeared within 48 hours) and a late lesion (old papule on hyperpigmented area or hyperkeratotic lesions) on each subject.

All skin biopsies were sliced with a microtome to 3$4 \mu \mathrm{m}$ thickness; 3 or more slices of the same lesion (A or B) were prepared on an objective glass (slide). Fifty slides of each early and late lesions were then stained with $\mathrm{HE}$ and IP using monoclonal antibodies against $\mathrm{T}$ cells, T-helper (CD4+) cells, T-supressor/ cytotoxic (CD8+) cells, B cells, Langerhans cells and antigen-presenting cells which expressed the $\alpha$ and $\beta$-chain of HLA-DR (APCs/HLA-DR $\alpha$ or APCS/HLA-DR $\beta$ ).

To identify specific cells (T-cells, CD4+ cells, CD8+ cells, B cells, Langerhans cells, and APCs), the monoclonal antibodies UCHL-1(CD45RO), antihuman CD4+ cells, antihuman CD8+ cells, CD20 or L26. protein S-100, antihuman HLA-DR $\alpha$ and antihuman HLA-DR $\beta$ or CR3/43, respectively were used. These monoclonal antibodies were made by Dako Corporation.

The substrate for all IP staining was 3'3'diaminobenzidine (DAB), ${ }^{9-14}$ except for epidermal Langerhans cells (LCs) was 3'amino-9' aethylcarbazone (AEC). ${ }^{15,16}$ From skin biopsy 100 were eligible for the study, each lesion had one HE-stained slide and seven IPstained slides, one for each type of cells. The positive control specimens were taken from the tonsil/ appendix tissue while negative (unstained) control specimens were from the same lesions.

Non-specific inflammatory cells (lymphocytes, histiocytes, eosinophils, basophils, mast cells), and specific inflammatory cells (B cells, T cells, CD4+ cells, CD8+ cells, Langerhans cells, HLA-DR $\alpha /$ APCs and HLA-DRß/APCs), in the two most representative slices on each slide were examined. The total absolute numbers of cells per $1 \mathrm{~cm}^{2}$ and the proportions of those inflammatory cells in 2 parts of the lesion (the central and the edge) were calculated. The slides were examined by using $1 \mathrm{~cm}^{2}$ net-grid eyepiece placed on the ocular lens, under $400 x$ magnification. The 
average (mean \pm standard deviation) number of infiltrating cells was calculated from the total number $/ 1 \mathrm{~cm}^{2}$ of that particular cell. The average number of a particular cell in the central part of the lesions was the total number $/ 1 \mathrm{~cm}^{2}$ of that cells in three parts of each slice divided by six ( $3 \times 2$ slices). Mann-Whitney statistical method (U test) was used to compare the quantity of inflammatory cell infiltration at the central part and the edge of early and late lesions.

The immunogenetic factors of human leukocyte antigen (HLA) were performed in 41 cases by using HLA-class I Asian dry traylot \# 1A based on microlymphocytotoxic reaction.

\section{RESULTS}

\section{The histopathological characteristics of $\mathrm{HE}$ staining}

Histopathological examinations revealed the characteristics of corneal layer in early and late lesions and are presented in Table 1. Normal corneal layer was seen in $80 \%$ cases of early lesions and $12 \%$ of late lesions. On the contrary, orthokeratosis was noted in $88 \%$ cases of late lesions and appeared in only $20 \%$ cases of early lesions. The basket weave configuration of comeal layer was pronounced in early lesions $(48 \%)$. All findings were statistically significant $(\mathrm{p}<0.05)$.

Table 1. The characteristics of the corneal layer of early and late prurigo Hebra lesions

\begin{tabular}{|c|c|c|c|}
\hline \multirow{2}{*}{$\begin{array}{l}\text { Histopathological } \\
\text { feature }\end{array}$} & \multicolumn{2}{|c|}{ Positivity in nos. of specimens } & \multirow[t]{2}{*}{$\mathbf{X}^{2}$ test } \\
\hline & $\begin{array}{l}\text { Early lesions } \\
\quad(\mathrm{n} 1=50)\end{array}$ & $\begin{array}{l}\text { Late lesions } \\
(\mathbf{n} 2=50)\end{array}$ & \\
\hline - Normal & $40(80 \%)$ & $16(12 \%)$ & $<0.05^{*}$ \\
\hline - Hyperkeratosis & $10(20 \%)$ & $44(88 \%)$ & $<0.05 *$ \\
\hline $\begin{array}{l}\text { : orthokeratosis } \\
\text { : parakeratosis }\end{array}$ & $5(10 \%)$ & $10(20 \%)$ & $>0.05$ \\
\hline \multicolumn{4}{|l|}{$\begin{array}{l}\text { - The figure of corneal } \\
\text { layer }\end{array}$} \\
\hline - compact (1) & $4(8 \%)$ & $5(10 \%)$ & $>0.05$ \\
\hline - lamellar (2) & $2(4 \%)$ & $4(8 \%)$ & $>0.05$ \\
\hline - basket weave (3) & $24(48 \%)$ & $9(18 \%)$ & $<0.05 *$ \\
\hline$-(1+2)$ & $24(48 \%)$ & $9(18 \%)$ & $<0.05 *$ \\
\hline$-(1+3)$ & $6(12 \%)$ & $4(8 \%)$ & $>0.05$ \\
\hline$-(2+3)$ & $4(8 \%)$ & $3(6 \%)$ & $>0.05$ \\
\hline$-(1+2+3)$ & $5(10 \%)$ & $1(2 \%)$ & $<0.05 *$ \\
\hline - (3)+parakeratotic & $2(4 \%)$ & $1(2 \%)$ & $>0.05$ \\
\hline - $(1+3)+$ parakeratc tic & $2(4 \%)$ & $1(2 \%)$ & $>0.05$ \\
\hline$-(2+3)+$ parakeratotic & $1(2 \%)$ & $5(10 \%)$ & $<0.05^{*}$ \\
\hline
\end{tabular}

Note : The significant difference at $p<0.05$
The characteristics of the epidermal layers (including granulosum, spinosum and basal layers) of early and late lesions of prurigo Hebra are presented in table 2. The thickening of the granulosum layer was more frequently found in the early lesions than in the late lesions; the difference was significant $(p<0.05)$. On the other hand, the thinning of granulosum layer was observed more frequently in the late cases than in early ones, statistically significant at $p<0.05$. Acanthosis, irregular papillomatosis, and hyperpigmentation of the basal layer were more frequently found in late lesions than in early lesions, statistically significant at $\mathrm{p}<0.05$.

In the central part of specimens patchy perivascular infiltrates were seen especially in the upper and lower dermis. Lymphocytes, histiocytes and eosinophils were abundant, while PMNs were few. Forty-nine (98\%) specimens of early lesions showed vasodilatation and vascular oedema with protrusion of endothelial cells into the lumen. Seven (14\%) specimens of late lesions showed collagen thickening and a relative decrease of fibrocytes.

Table 2. Epidermal characteristics of early and late prurigo Hebra lesions

\begin{tabular}{|c|c|c|c|}
\hline \multirow{2}{*}{$\begin{array}{l}\text { Epidermal layer } \\
\text { characteristics }\end{array}$} & \multicolumn{2}{|c|}{ Positivity in nos. of specimens } & \multirow[t]{2}{*}{$X^{2}$ test } \\
\hline & $\begin{array}{l}\text { Early lesions } \\
\quad(\mathbf{n} \mathbf{1 = 5 0})\end{array}$ & $\begin{array}{l}\text { Iate lesions } \\
\qquad(\mathrm{n} \mathbf{2}=\mathbf{5 0})\end{array}$ & \\
\hline \multicolumn{4}{|l|}{ Granulosum layer } \\
\hline $\begin{array}{l}\text { Normal } \\
\text { Abnormal: }\end{array}$ & $16(32 \%)$ & $20(40 \%)$ & $>0.05$ \\
\hline - thickening & $31(62 \%)$ & $15(30 \%)$ & $<0.05^{*}$ \\
\hline - thinning & $3(6 \%)$ & $15(30 \%)$ & $<0.05^{*}$ \\
\hline $\begin{array}{l}\text { Spinosum layer } \\
\text { Normal } \\
\text { Abnomnal: }\end{array}$ & & & \\
\hline - spongiosis & $26(52 \%)$ & $8(16 \%)$ & $<0.05^{*}$ \\
\hline - acanthosis & $13(26 \%)$ & $12(24 \%)$ & $>0.05$ \\
\hline - spongiosis+ & $7(14 \%)$ & $26(52 \%)$ & $<0.05^{*}$ \\
\hline acanthosis & $4(8 \%)$ & $4(8 \%)$ & $>0.05$ \\
\hline \multicolumn{4}{|l|}{ Basal layer } \\
\hline $\begin{array}{l}\text { Normal } \\
\text { Abnomnal: }\end{array}$ & $32(64 \%)$ & $10(20 \%)$ & $<0.05^{*}$ \\
\hline - papillomatosis & $12(24 \%)$ & $17(34 \%)$ & $>0.05$ \\
\hline - psoriasiform & $5(10 \%)$ & $3(6 \%)$ & $>0.05$ \\
\hline $\begin{array}{l}\text { - irregular } \\
\text { papillomatosis }\end{array}$ & $1(2 \%)$ & $20(40 \%)$ & $<0.05^{*}$ \\
\hline \multicolumn{4}{|l|}{ Basal pigmentation } \\
\hline Normal & $38(76 \%)$ & $23(46 \%)$ & \\
\hline Abnormal & $12(24 \%)$ & $27(54 \%)$ & $<0.05 *$ \\
\hline
\end{tabular}

Note: $\quad$ significant difference at $\mathrm{p}<0.05$

Table 3 displays the average numbers of non-specific inflammatory cells found in the central part of the specimens. PMNs infiltrates were seen in 13 of 50 
early-lesion and 9 of 50 late-lesion specimens. The number of PMNs in early lesions was greater than in the late ones. Lymphocytes and histiocytes were abundant, their number in the late lesions were greater than in the early ones, statistically these findings were not significant $(p>0.05)$. In the early lesions, eosinophils were more pronounced; their number was greater than that in the late lesions with a highly significant difference $(p<0.01)$. In 5 early-lesion specimens, the number of eosinophils found were 50100 cells $/ 1 \mathrm{~cm}^{2}$; they infiltrated uncommonly even in the interstitial part of the subdermis, giving the appearance of flame figure. Mast cells, basophils, and plasma cells were not seen.

\section{The immunohistopathological findings}

\section{T, CD4+, CD8+, and B cells}

The absolute numbers of $\mathrm{T}, \mathrm{CD} 4+$ cells, CD8+ cells, and $\mathrm{B}$ cells in the central part of the early and late lesions are showed in Table 4. Statistical distribution of T, CD4+ cells , CD8+ cells, B cells, lymphocytes and histiocytes did not follow the normal curve, except for the CD4+ cells in the early lesions, therefore Mann Whitney test (U test) was used for analysis. The absolute numbers of $\mathrm{T}$ and $\mathrm{CD} 4+$ cells in the early lesions were greater than in the late ones, but not statistically significant $(\mathrm{p}>0.05)$. The absolute

Table 3. The non-specific inflammatory cells in the central part of the lesions

\begin{tabular}{|c|c|c|c|c|c|c|c|}
\hline \multirow[t]{2}{*}{ Type of cells } & \multicolumn{3}{|c|}{ Early lesions $(n=50)$} & \multicolumn{3}{|c|}{ Late lesions $(n=50)$} & \multirow[t]{2}{*}{$\mathbf{P}$} \\
\hline & $\mathbf{N \# )}$ & MeantSD & Med. & $\mathbf{N \# )}$ & Mean \pm SD & Med. & \\
\hline 1. PMNs & 13 & $8 \pm 2$ & 0 & 9 & $1 \pm 3$ & 0 & $>0.05$ \\
\hline 2. Lymphocytes & 50 & $89 \pm 59$ & 65 & 50 & $85 \pm 36$ & 73 & $>0.05$ \\
\hline 3. Histiocytes & 50 & $40 \pm 24$ & 36 & 50 & $48 \pm 25$ & 43 & $>0.05$ \\
\hline 4. Eosinophils & 46 & $10 \pm 11$ & 9 & 30 & $5 \pm 9$ & 3 & $<0.01 * *$ \\
\hline 5. Other cells \#) & & - & & & - & & \\
\hline
\end{tabular}

Note: $\mathrm{N \# )} \mathrm{=number} \mathrm{of} \mathrm{positive} \mathrm{specimens,} \mathrm{Mean} \mathrm{=} \mathrm{average,} \mathrm{SD}=$ standard deviation, Med. = median, \#\#) Mast cells, basophils, plasma cells were not found. Significant different at $\mathrm{p}<0.05, * *$ highly significant difference at $\mathrm{p}<0.01$

Table 4. The absolute numbers of T,CD4+ cells ,CD8+ cells, and B cells in the central part of prurigo Hebra lesions

\begin{tabular}{|c|c|c|c|c|c|}
\hline \multirow{2}{*}{$\begin{array}{l}\text { The absolute number of } \\
\text { cells } / 1 \mathrm{~cm}^{2}\end{array}$} & \multicolumn{2}{|c|}{ Early lesions (n1=50) } & \multicolumn{2}{|c|}{ Late lesions (n2=50) } & \multirow[t]{2}{*}{$\mathbf{U}$ test } \\
\hline & Mean \pm SD & Median & Mean \pm SD & Median & \\
\hline 1. T cells & $72.68 \pm 44.22$ & 58.50 & $57.24 \pm 33.59$ & 51.50 & $p>0.05$ \\
\hline Lymphocytes & $55.06 \pm 28.38$ & 53.50 & $51.66 \pm 25.96$ & 50.55 & $p>0.05$ \\
\hline Histiocytes+lymphocytes & $91.94 \pm 41.43$ & 86.50 & $87.30 \pm 41.78$ & 86.50 & $p>0.05$ \\
\hline 2. CD4+ cells & $41.40 \pm 35.44$ & 28.00 & $27.70 \pm 18.00$ & 22.29 & $\mathrm{p}>0.05$ \\
\hline Lymphocytes & $60.18 \pm 31.01$ & 60.00 & $62.04 \pm 27.02$ & 65.50 & $p>0.05$ \\
\hline Histiocytes +lymphocytes & $97.79 \pm 45.38$ & 94.00 & $102.94 \pm 41.77$ & 99.00 & $p>0.05$ \\
\hline 3. CD8+ cells & $20.84 \pm 15.86$ & 17.50 & $20.00 \pm 16.00$ & 17.00 & $p>0.05$ \\
\hline Lymphocytes & $68.52 \pm 35.32$ & 70.50 & $67.96 \pm 28.04$ & 70.50 & $p>0.05$ \\
\hline Histiocytes+lymphocytes & $105.68 \pm 48.88$ & 108.00 & $108.98 \pm 46.56$ & 107.50 & $p>0.05$ \\
\hline 4. B cells & $4.57 \pm 3.83$ & 4.00 & $5.76 \pm 3.00$ & 5.71 & $\mathrm{p}>0.05$ \\
\hline Lymphocytes & $93.73 \pm 43.62$ & 92.00 & $73.43 \pm 33.88$ & 74.00 & $p>0.05$ \\
\hline Histiocytes +lymphocytes & $37.00 \pm 57.00$ & 130.00 & $119.81 \pm 43.52$ & 124.00 & $p>0.05$ \\
\hline \multicolumn{6}{|l|}{ 5. Ratio } \\
\hline $\begin{array}{l}\text { CD4+ cells: } \\
\text { CD8+ cells }\end{array}$ & $2.90 \pm 1.89$ & 3.10 & $1.847 \pm \quad 1.18$ & 1.58 & $\mathrm{p}<0.05^{*}$ \\
\hline
\end{tabular}

Note: $S D=$ standard deviation, $U$ test with significant difference at $p \leq 0.05$, highly significant difference at $p \leq 0.01$ 
number of CD8+ cells in the early lesions was similar to the late ones. No specific arrangement distributions of CD4+ and CD8+ cells were seen in the patchy infiltrates. The CD4+: CD8+ ratio in the early lesions was higher than that in late lesions, statistically significant at $\mathrm{p}<0.05$. Data showed that $\mathrm{CD} 4+$ cells were predominant both in the early and late lesions. Surprisingly, B cells were few in number; their number in the late lesions was greater than that in early lesions, and were not statistically significant ( $>0.05$ ). The absolute numbers of lymphocytes and histiocytes in the early lesions were greater than those in late lesions, but not statistically significant ( $p>0.05$ ).

The proportion meaning the percentage of the absolute number of $\mathrm{T}, \mathrm{CD} 4+, \mathrm{CD} 8+$ cells and $\mathrm{B}$ cells in the central part of the specimens to the total number of lymphocytes in each slides $/ 1 \mathrm{~cm}^{2}$. The proportions were presented in Table 5. The CD4+ cell proportion in the early lesions was statistically greater than that in the late lesions $(\mathrm{p}<0.01)$. The proportion of $T$ cells was found in great number (51$57 \%$ ), while B cells just in a few (3-5\%). Other cells showed difference between early and late lesions, but were not statistically significant. In spite of statistical calculations, the CD4+ cells seemed to predominate (over CD8+ cells) in both the early and late lesions.

\section{Langerhans and HLA-DR-expressing APCs}

The absolute numbers of $\mathrm{LCs} / 1 \mathrm{~cm}^{2}$ are presented in Table 6. The absolute number of epidermal LCs that stained with protein S-100 in the late lesions was statistically greater than that in early lesions $(\mathrm{p}=0.05)$. LCs expressed the HLA-DR $\alpha$ and $\beta$ monoclonal antibody. The numbers of both LCs/HLA-DR $\alpha$ and LCs/HLA-DR $\beta$ in late lesions were also greater than that in early lesions and were statistically significant $(\mathrm{p}=0.01)$.

Table 5. T, CD4+, CD8+, B cells proportion at central part of early and late lesions of prurigo Hebra

\begin{tabular}{|c|c|c|c|c|c|}
\hline \multirow{2}{*}{$\begin{array}{c}\text { Cells proportion to } \\
\text { lymphocytes population }\end{array}$} & \multicolumn{2}{|c|}{ Early lesions $(\mathrm{n} 1=\mathbf{5 0})$} & \multicolumn{2}{|c|}{ Late lesions $(\mathrm{n} 2=\mathbf{5 0})$} & \multirow[t]{2}{*}{ U test } \\
\hline & Mean \pm SD & Median & Mean \pm SD & Median & \\
\hline T cells proportion & $55.30 \pm 14.40$ & 57.10 & $51.80 \pm 14.90$ & 51.50 & $p>0.05$ \\
\hline CD4+cells proportion & $37.80 \pm 15.20$ & 38.60 & $30.10 \pm 15.04$ & 28.10 & $\mathrm{p}<0.01 * *$ \\
\hline CD8+ cells proportion & $24.40 \pm 14.90$ & 20.00 & $22.60 \pm 12.10$ & 20.30 & $p>0.05$ \\
\hline B cells proportion & $5.80 \pm 7.30$ & 3.20 & $9.10 \pm 1.17$ & 4.70 & $\mathrm{p}>0.05$ \\
\hline $\begin{array}{l}\mathrm{CD} 4+\text { : } \mathrm{CD} 8+\text { cells } \\
\text { ratio (in proportion) }\end{array}$ & $2.70 \pm 4.01$ & 1.86 & $1.14 \pm 6.69$ & 1.02 & $p>0.05$ \\
\hline
\end{tabular}

Note: $\mathrm{SD}=$ standard deviation, significant difference at $\mathrm{p}<0.05$, highly significant difference at $\mathrm{p}<0.01$

Table 6. The numbers of epidermal Langerhans cells in the central part of the lesions

\begin{tabular}{lcccccc}
\hline \multirow{2}{*}{$\begin{array}{l}\text { Epidermal Langerhans } \\
\text { Cells }\end{array}$} & \multicolumn{2}{c}{ Early lesions $(\mathbf{n = 5 0})$} & \multicolumn{2}{c}{ Late lesions $(\mathbf{n = 5 0})$} & \multicolumn{2}{c}{ U test } \\
& Mean \pm SD & Median & Mean \pm SD & Median & \\
\hline LCs /S-100 & $3.58 \pm 2.11$ & 4.00 & $4.50 \pm 2.91$ & 5.00 & $\mathrm{p}=0.05^{*}$ \\
LCs/HLA-DR $\alpha$ & $3.96 \pm 2.44$ & 4.00 & $5.30 \pm 2.69$ & 6.00 & $\mathrm{p}=0.01^{* *}$ \\
LCs/HLA-DR $\beta$ & $4.75 \pm 2.54$ & 5.00 & $6.14 \pm 3.03$ & 6.50 & $\mathrm{p}=0.01^{* *}$ \\
\end{tabular}

Note: $\mathrm{SD}=$ standard deviation, $\mathrm{LC}=$ Langerhans cell, $\mathrm{U}$ test with $*$ significant difference at $\mathrm{p} \leq 0.05$, highly significant difference at $\mathrm{p} \leq 0.01 ; * *$ 
The absolute numbers of HLA-DR-expressing APCs are showed in Table 7. The absolute numbers of HLA-DR ( $\alpha$ and $\beta$ chains)-expressing APCs in the early lesions were greater than those in late lesions, but were not statistically significant ( $p>0.05$ ).

The expression of HLA-DR- $\alpha$ and HLA-DR- $\beta$ on $\mathrm{APCs}$ in the central part of early lesions were as seen in the part of early lesions were as seen in the Scatter-diagram 1. There was a positive correlation between the expressions of HLA-DR $\alpha$ and $\beta$ in APCs, the coefficient correlation ( $\mathrm{r}$ ) was 0.618 with 95\%C.I. $=0.410-0.765$. This correlation was calculated by statistics with confidence/C.I.A. program. HLA-DR expressed the $\beta$ chain more stronger than the $\alpha$ chain in dermal APCs, but in epidermal LCS, the expression of $\beta$ chain was as good as $\alpha$ chain.

The proportion of HLA-DR- $\alpha$ - and HLA-DR- $\beta$ expressing APCs were the ratio of the absolute numbers of each APCs to the total number (sum) of lymphocytes + histiocytes $+\mathrm{APC} / 1 \mathrm{~cm}^{2}$ The

Table 7. The absolute numbers of HLA-DR-expressing APCs in the central part of early and late lesions of prurigo Hebra

\begin{tabular}{|c|c|c|c|c|c|}
\hline \multirow[t]{2}{*}{ Cells } & \multicolumn{2}{|c|}{ Early lesions $(\mathrm{n} 1=50)$} & \multicolumn{2}{|c|}{ Late lesions (n2=50) } & \multirow[t]{2}{*}{$\mathbf{U}$ test } \\
\hline & Mean + SD & Median & Mean \pm SD & Median & \\
\hline APCs/HLA-DR $\alpha$ & $70.42 \pm 38.09$ & 75.00 & $67.98 \pm 31.56$ & 65.50 & $p>0.05$ \\
\hline Lymphocytes & $53.14 \pm 29.53$ & 48.00 & $48.18 \pm 26.40$ & 44.50 & $p>0.05$ \\
\hline Histiocytes+lymphocytes & $78.24 \pm 42.19$ & 76.50 & $78.92 \pm 40.15$ & 78.00 & $\mathrm{p}>0.05$ \\
\hline APCs/HLA-DR $\beta$ & $79.42 \pm 38.09$ & 83.00 & $77.94 \pm 39.09$ & 78.00 & $\mathrm{p}>0.05$ \\
\hline Lymphocytes & $50.56 \pm 27.86$ & 50.00 & $47.78 \pm 31.37$ & 42.00 & $\mathrm{p}>0.05$ \\
\hline Histiocytes+lymphocytes & $75.16 \pm 38.35$ & 70.00 & $72.94 \pm 39.09$ & 78.00 & $\mathrm{p}>0.05$ \\
\hline
\end{tabular}

Note: $\quad \mathrm{SD}=$ standard deviation, $\mathrm{APC} s=$ antigen-presenting cells

$U$ test with significant difference at $p \leq 0.05$, highly significant difference $p \leq 0.01$.

HLA-DRalfa and HLA-DRbetha EXPRESSING ANTIGEN PRESENTING CELLS IN PRURIGO HEBRA

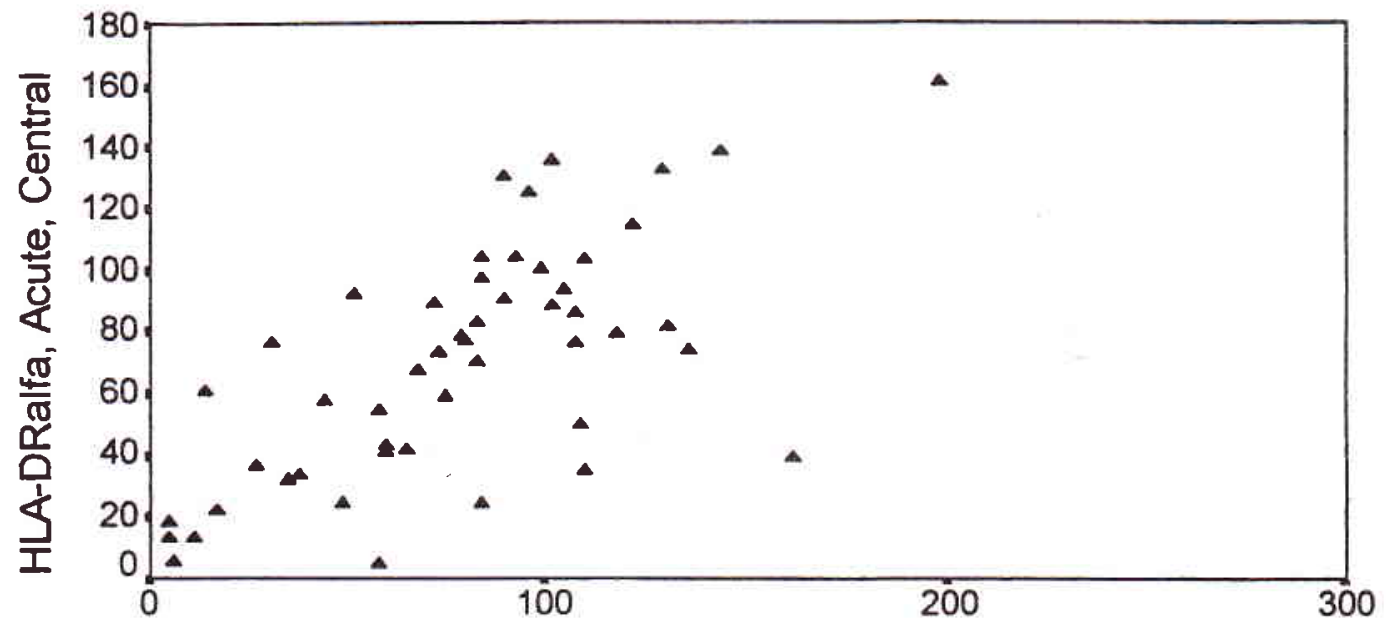

HLA-DRbetha, Acute, Central

Scatter diagram-1. The expression of HLA-DR $\alpha$ and HLA-DRB on APCs 
proportion of of HLA-DR- $\alpha$ - and HLA-DR- $\beta$ expressing APCs in the central part of the lesions is presented in Table 8. The proportion of both HLADR- $\alpha$ - and HLA-DR- $\beta$-expressing APCs in the late lesions were greater than that in early lesions, but not statistically significant $(\mathrm{p}>0.05)$.

The correlation between inflammatory cells, severity, and human leukocyte antigen

In order to improve the correlation between inflammatory cells in early lesions, the severity of the disease and immunogenetic factors of human leukocyte antigen (HLA), were performed in 41 of 50 subjects with prurigo Hebra. Forty one prurigo Hebra cases consisting of 17 mild and 24 severe condition. Female was the majority ( 28 cases).

The amounts of cell infiltrate in early and late lesions of 41 prurigo Hebra is shown in Table 9. Statistically the distributions of non-specific and specific cells were not normal, Mann Whitney method was used for statistical analysis. There is no significant difference between the specific inflammatory and nonspecific cells in early and late lesions. Correlation between B and $\mathrm{T}$ cells, B and eosinophil, LCs and T, CD4+, and $\mathrm{CD} 8+$ cells were weak and were not statistically significant.

Table 8. The proportions of HLA-DR- $\alpha$ and HLA-DR- $\beta$ expressing APCs in the central part of prurigo Hebra lesions

\begin{tabular}{|c|c|c|c|c|c|}
\hline \multirow{2}{*}{$\begin{array}{l}\text { Antigen- presenting } \\
\text { cells }\end{array}$} & \multicolumn{2}{|c|}{ early lesions ( $n=50$ ) } & \multicolumn{2}{|c|}{ late lesions $(\mathbf{n}=\mathbf{5 0})$} & \multirow[t]{2}{*}{$\mathbf{U}$ test } \\
\hline & Mean \pm SD & Median & Mean \pm SD & Median & \\
\hline APCs/HLA-DR $\alpha$ & $47.20 \pm 15.60$ & 45.40 & $46.30 \pm 13.70$ & 48.30 & $\mathrm{p}>0.05$ \\
\hline APCs / HLADR $\beta$ & $50.10 \pm 16.80$ & 54.10 & $.52 .00 \pm 18.10$ & 54.60 & $\mathrm{p}>0.05$ \\
\hline
\end{tabular}

Note: $\quad \mathrm{SD}=$ standard deviation, $\mathrm{U}$ test with significant difference $\mathrm{p} \leq 0.05$, highly significant difference $\mathrm{p} \leq 0.01 . \quad \mathrm{APC}=$ antigen-presenting cells

Table 9. Inflammatory cells in early lesions of prurigo Hebra cases $(n=41)$

\begin{tabular}{lcccc}
\hline Cells & Mean \pm SD & Median & $\begin{array}{c}\text { Minimum - } \\
\text { maximum }\end{array}$ & 95\% C.I. \\
\hline T cells & $72.7 \pm 43.21$ & 57 & $10-87$ & $59.1 ; 86.3$ \\
CD4+ cells & $41.60 \pm 36.22$ & 27 & $4-137$ & $30.2 ; 53.0$ \\
CD8+ cells & $18.24 \pm 13.78$ & 16 & $1-59$ & $13.9 ; 22.6$ \\
B cells & $3.68 \pm 4.08$ & 2 & $0-15$ & $2.4 ; 4.97$ \\
APCs/ HLA-Dro & $68.63 \pm 38.35$ & 73 & $5-161$ & $40.1 ; 41.9$ \\
APCs/ HL-DR $\beta$ & $74.78 \pm 42.22$ & 83 & $5-198$ & $61.5 ; 88.1$ \\
LC & $3.48 \pm 2.11$ & 4 & $0-10$ & $2.8 ; 4.2$ \\
Eosinophils & $19.36 \pm 24.38$ & 10 & $0-112$ & $18.6 ; 20.1$ \\
\hline
\end{tabular}

Note: $\mathrm{LC}=$ Langerhans cells, APCs = antigen-presenting cells, 95\% C.I. $=95 \%$ confidence interval 
Correlation between T, CD4+, CD8+ cells, APCs and eosinophils

Table 10. shows that correlation between APCs and $\mathrm{T}$ cells and subsets were strong $(r=0.32-0.49)$, and significant with $95 \%$ C. I, save for the correlation between APCs/HLA-DR $\beta$ and CD8+ cells $(r=0.24)$. The strong correlation between APCs and T cells and their subsets suggesting that this condition might lead to chronic inflammation of prurigo Hebra. The abundance of APCs meant that a person with prurigo Hebra was exposed to antigens or triggering factors for a long time and thus the interaction with $\mathrm{T}$ cells and their subsets did follow. The correlation between $\mathrm{T}$ cells and APCs/HLA-DR $\beta$ was positive as shown in Scatter diagram 2.

In this analysis, the correlation between eosinophils and $\mathrm{T}$ cells $(\mathrm{r}=-0.05,95 \%$ C.I. $=-0.385 ; 0.255), \mathrm{CD} 4+$ cells ( $r=-0.09,95 \%$ C.I. $=-0.390 ; 0.221)$, and CD8+ cells ( $r=-0.19$ with $95 \%$ C.I. $-0.469 ; 0.126)$ were weak. It was doubted whether the presence of eosinophils was due to a collaboration between typeIV and type-I hypersensitivity, or to insect bite reaction itself. Statistical analysis also showed that the correlation between eosinophils and APCs/HLA$\mathrm{DR} \alpha(\mathrm{r}=0.16$ with $95 \%$ C.I. $-0.367 ; 0.246)$ and the correlation between eosinophils and APCs/HLA-DR $\beta$ $(r=0.14$ with $95 \%$ C.I. $=-0.180 ; 0.425)$ were both weak.
Table 10. The correlations between APCs and T, CD4+, and CD8+ cells

\begin{tabular}{|c|c|c|}
\hline Correlation between & $\begin{array}{c}\text { Correlation } \\
\text { coefficient (r) } \\
\text { Spearman's } \\
\text { correlation }\end{array}$ & 95\% C.I. \\
\hline $\begin{array}{l}\text { APCs/HLA-DR } \alpha \text { and } \\
\mathrm{T} \text { cells }\end{array}$ & 0.39 & $0.090 ; 0.624 *$ \\
\hline $\begin{array}{l}\text { APsC/HLA-DR } \alpha \text { and } \\
\text { CD } 4+\text { cells }\end{array}$ & 0.32 & $0.010 ; 0.578 *$ \\
\hline $\begin{array}{l}\text { APCs/HLA-DR } \alpha \text { and } \\
\text { CD } 8+\text { cells }\end{array}$ & 0.49 & $0.188 ; 0.678 *$ \\
\hline $\begin{array}{l}\text { APCs/HLA-DR } \beta \text { and } \\
\mathrm{T} \text { cells }\end{array}$ & 0.49 & $0.217 ; 0.694 *$ \\
\hline $\begin{array}{l}\text { APCs/HLA-DR } \beta \text { and } \\
\text { CD } 4+\text { cells }\end{array}$ & 0.46 & $0.179 ; 0.674 *$ \\
\hline $\begin{array}{l}\text { APCs/HLA-DR } \beta \text { and } \\
\text { CD } 8+\text { cells }\end{array}$ & 0.24 & $-0.06 ; 0.523$ \\
\hline
\end{tabular}

Note: $\mathrm{APC}=$ antigen-presenting cells, confidence interval

Correlation between severity of prurigo Hebra and inflammatory cells

Table 11 shows the quantity of non-specific and specific inflammatory cells in 24 severe cases and 17 mild cases of prurigo Hebra. There was no significant difference between the amount of non-specific and specific cell infiltration in severe and mild cases, except for the eosinophils. In severe cases, eosinophlis were predominant $(p<0.05)$.

\section{The correlation between Tcells and}

\section{HLA-DR expressing APCs in prurigo Hebra}

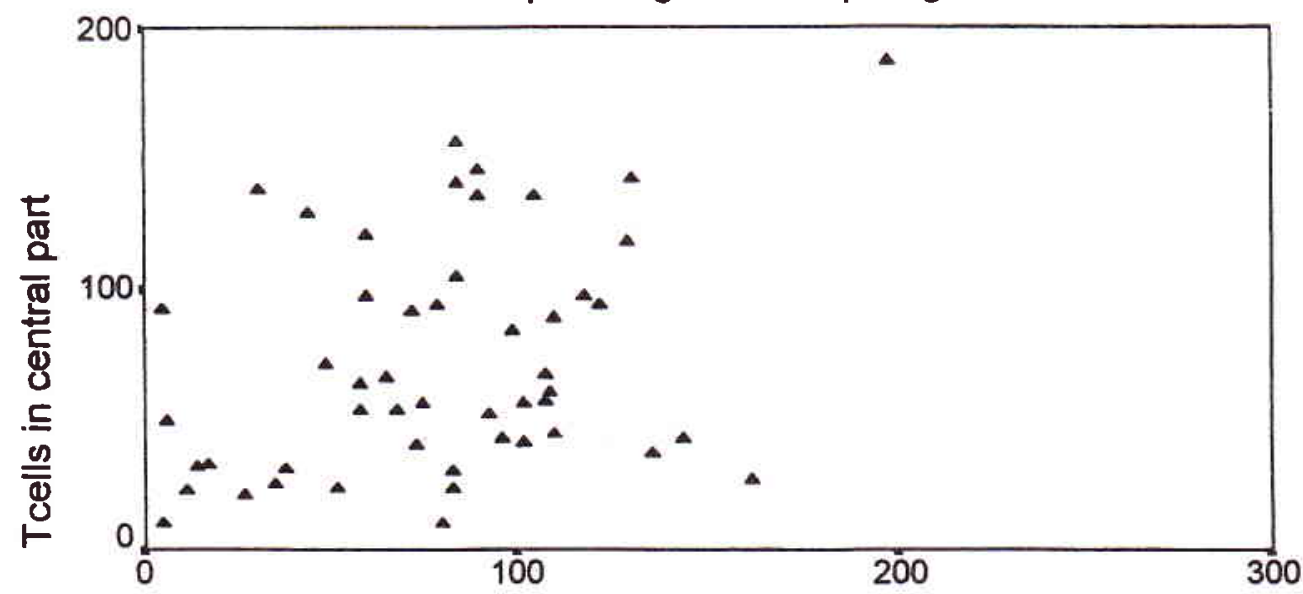

HLA-DRalfa-Antigen presenting cells (central part) 
The analysis showed that correlation between severity of prurigo Hebra and the quantities of $\mathrm{T}$ cells $(\mathrm{r}=$ $0.18), \mathrm{CD} 4+$ cells $(\mathrm{r}=0.19), \mathrm{CD} 8+$ cells $(\mathrm{r}=0.20)$, and LCs $(r=-0.22)$ were not statistically significant. However, the correlation between severity of prurigo Hebra and eosinophils $(r=0.25)$ was strong. It is assumed that the more the number of eosinophils present, the more severe the condition would be.

\section{Correlation between severity of prurigo Hebra, eosinophils and HLA}

Eosinophils in severe cases was more pronounced than that in mild ones, and was statistically significant $(\mathrm{p}<0.05)$. Further analysis with $\mathrm{X}^{2}$ trend (Table 12) in
3 groups of prurigo Hebra with severe condition showed that 9 cases had eosinophils $0-5 / 1 \mathrm{~cm}^{2} ; 9$ cases had $6-10$, and 6 cases had $\geq 11$, the increasing relative risk $(\mathrm{RR})$ was not significant (score test $\mathrm{X}^{2}$ for trend $=1.129, \mathrm{p}>0.05$ ).

The same analysis in 17 mild cases showed that 11 mild cases had 0-5 eosinophils, 4 cases had 6-15 eosinophils, and 2 cases had $\geq 16$ eosinophils, the decreasing RR was not significant (score test $X^{2}$ for trend $=1.595, \mathrm{p}>0.05$ ). Although it was not significant, it suggested that prurigo Hebra with severe condition had eosinophils $>5 / 1 \mathrm{~cm}^{2}$ for those with mild condition $<5 / 1 \mathrm{~cm}^{2}$.

Table 11. Inflammatory cells in severe and mild cases of prurigo Hebra

\begin{tabular}{|c|c|c|c|c|c|}
\hline \multirow[t]{2}{*}{ Inflammatory cells } & \multicolumn{2}{|c|}{ Severe $(n=24)$} & \multicolumn{2}{|c|}{ Mild (n=17) } & \multirow{2}{*}{$\begin{array}{c}\text { U test } \\
\text { p }\end{array}$} \\
\hline & Mean \pm SD & Median & Mean \pm SD & Median & \\
\hline $\mathrm{T}$ cells & $75 \pm 48.84$ & 65.5 & $68 \pm 34.72$ & 60.0 & $>0.05$ \\
\hline CD4+ cells & $42 \pm 38.17$ & 29.5 & $41 \pm 35.22$ & 22.0 & $>0.05$ \\
\hline CD8+ cells & $18 \pm 12.40$ & 16.0 & $18 \pm 15.95$ & 11.0 & $>0.05$ \\
\hline B cells & $3 \pm 03.50$ & 2.5 & $3.5 \pm 03.70$ & 2.0 & $>0.05$ \\
\hline APCs/HLA-DR $\alpha$ & $73 \pm 41.21$ & 73.5 & $62 \pm 33.95$ & 70.0 & $>0.05$ \\
\hline APCs/HLA-DR $\beta$ & $76 \pm 47.76$ & 84.0 & $72 \pm 34.12$ & 75.0 & $>0.05$ \\
\hline $\mathrm{LCs}$ & $3 \pm 01.80$ & 3.0 & $4 \pm 01.96$ & 4.0 & $>0.05$ \\
\hline Eosinophils & $21 \pm 23.24$ & 13.5 & $17 \pm 26.44$ & 6.0 & $<0.05^{*}$ \\
\hline
\end{tabular}

Note: APCs = antigen-presenting cells. LCs= Langerhans cells. Significant difference at $p<0.05$

$\mathrm{U}$ test $=$ Mann Whitney test

Table 12. The amount of eosinophils in severe cases of prurigo Hebra $(n=24)$

\begin{tabular}{|c|c|c|c|c|c|c|c|}
\hline $\begin{array}{l}\text { Groups } \\
\left.\text { (eosinophils } / \mathrm{cm}^{2}\right)\end{array}$ & $\begin{array}{l}\text { Nos. of } \\
\text { specimens }\end{array}$ & Expected & $\begin{array}{l}\text { Total } \\
\text { PH }\end{array}$ & $\mathbf{R R}$ & 95\% C.I. & $\begin{array}{l}\text { Score test } \\
X^{2} \text { for trend }\end{array}$ & $p$ \\
\hline 1. $(0-5)$ & 9 & 11.7 & 20 & 0.745 & $0.383 ; 1.450$ & & \\
\hline II. (6-15) & 9 & 7.60 & 13 & 1.17 & $0.614 ; 2.240$ & & \\
\hline III. $>16$ & 6 & 4.68 & 8 & 1.21 & $0.597 ; 2.470$ & 1.129 & $>0.05$ \\
\hline
\end{tabular}

Note: Significant difference at $p<0.05 \quad 95 \%$ C. I. = confidence interval 
The Immunohistopthalogical features showed that the numbers of cells in early and late lesions were not significant difference, except for CD4+ cells, which were found significantly greater number in early lesions. In both the early and late lesions, the T, CD4+, CD8+ cells and APCs were found in great quantities. This finding was compatible with the feature of type-IV hypersensitivity. ${ }^{17,18}$

The abundance of APCs and T cells and its strong correlation probably indicates that the prurigo Hebra patients always exposure to extrinsic factors. ${ }^{17,18}$

Protein S-100 and monoclonal antibodies of HLADR- $\alpha$ and $\beta$ were both potential to use for epidermal LC identification. Langerhans epidermal cells stained with monoclonal antibodies of HLA-DR $\alpha$ or $\beta$ and protein S-100 with AEC substrate was seen in good configuration with its dendrite processus. The number in late lesions was significantly more profound than in early lesion, but the number was within normal limits $(2-8 \%)$.

B cells, which normally were not found in normal skin, ${ }^{17,18}$ were surprisingly found in few number The fact, that eosinophils were found in large amounts might have been related to CD4+ cells' domination, although statistically the correlation between $\mathrm{T}$ helper (Th) or CD4+ and eosinophils was not sigificant. As it is been known that $\mathrm{T}$ helper (CD4+) cells consist 2 subsets, T helper -1 (Th-1) and Th-2. Theoretically Th-2 cells collaborate with type-I hypersensitivity reactions. Th- 2 cells produce IL-3 and IL-5, cytokines that act as attracting mediator to eosinophils and potentially stimulate eosinophil migration to the inflammatory site. ${ }^{17,18}$ In this study Th-1 and Th-2 were not examined.

In this study the severity of prurigo Hebra was significantly correlated with hypereosinophils in skin lesions of prurigo Hebra patients with HLA-A10 and its splits.

\section{CONCLUSIONS}

The immunohistopathological feature revealed numerous inflammatory cells consisting $\mathrm{T}$ cells, CD4+ cells, CD8+ cells, T suppressor cells, $\mathrm{LC}$ cells and HLA-DR-expressing APCs. However the numbers of cells in early and late lesions were not statistically different, except for CD4+ cells, which were found in significantly greater number in early lesions. CD4+ cells were significantly predominant than $\mathrm{CD} 8+$ cells. The eosinophils were found in abundance, independent on the presence of mast cells, plasma cells, basiphils and B cells. The presence might be correlated with CD4+ cells' domination. The numbers of LC were within normal limits. The correlation between T cells and APCs were strong, it is indicated that prurigo Hebra patients always exposure to the external factors, especially insects bite. The severe cases may correlate with HLA-A10 and hypereosinophils in skin lesions. Considering the immunohistopathological findings it is assumed that the mechanisms of prurigo Hebra was a mixture between type-IV and type-I hypersensitivity reactions.

\section{Acknowledgement}

We would like to thank the head of the Pathology Department for the possibility of the study in immunohistochemistry. We are debtfull to Ms. Nunuk Kurniati and Ms. Neneng Komariah analysts, for their keen work in staining the immunoperoxydase specimens. Personally, I would like to thank Dra. Corry Wawolumaya, $\mathrm{PhD}, \mathrm{MPH}$ for statistical consultations.

\section{REFERENCES}

1. von Hebra F. Erythema multiforme, lichen simplex, prurigo, pityriasis rosea, rhinosklerosis. In: Shelley WB, Crissey JT, Stokes JH, Eds. Classics in clinical dermatology with biographical scketches. Oxford: Blackwell Scientific Publication; 1953. p. 110-2.

2. McKenna RW, Mc Kenna MW. Diseases of the skin. $6^{\text {th }}$ ed. London; Billaire Tindall and Cox; 1952. p. 331-52.

3. Ormsby DS, Montgomery H. Diseases of the skin. $6^{\text {th }}$ ed. Philadelphia: Lea \& Febriger; 1954. p. 197-203.

4. Rook A, Wilkinson DS, Ebling FJG. Eczema, lichen simplex and prurigo. In: Rook A, Ed. Rook's Textbook of Dermatology. London: Blackwell Scientific Publication; 1972. p. 84-9, 291-8

5. Arnold HL, Odomm RB, James WD. Andrew's diseases of the skin: clinical dermatology, $8^{\text {th }}$ ed. Philadelphia: WB Sauders Company; 1990. p. 157-8.

6. Kocsard E. The problem of prurigo. Austr J Derm 1962; 6:156-66.

7. Boediardja SA. Incidence of skin diseases in Indonesian children from 1981-1985. In: Urabe H, Kimura M, Yamamoto K, Ogawa $H$, Eds. Proceeding of the $4^{\text {th }}$ International Congress of Pediatric Dermatology. Tokyo: University Press of Tokyo; 1986. p. 371-82.

8. Medical record from Sub-Dept. of Pediatric Dermatology, Department of Dermato-Venereology, Dr. Cipto Mangunkusumo Hospital, Jakarta (1990-1997, in press.).

9. Boediardja SA, Soelarsito SA, Wisnu IM. Gambaran klinis dan histopatologi pada 159 penderita prurigo Hebra. 
Kumpulan makalah Ilmiah, Kongres PADVI ke-4. Ujung Pandang: 1986. h. 1158-65.

10. Occampo FA, Collade CM. Acute infantile prurigo. Clinico pathological correlation in 100 cases. Austr J Derm 1975; 16:169-73.

11. Jasani B, Schmid Kw. Immunocytochemistry in diagnostic histopathology. London: Churchill Livingstone; 1993. p.1-27.

12. Yaoita H. Enzyme labelled antibody method. In: Ueki H, Yaoita H, Eds. A colour atlas of dermatohistocytology, Tokyo: Wolfe Medical Publications Ltd; 1989. p. 8-10.

13. Takezaki S, Nishiyama S. Application of monoclonal antibodies. In: Ueki $\mathrm{H}$, Yaoita $\mathrm{H}$, Eds. A colour atlas of dermatohistocytology. Tokyo: Wolfe Medical Publications Ltd.; 1989. p.18-23

14. Hsu S-M, Raine L The use of avidin-biotin-peroxidase complex $(\mathrm{ABC})$ in diagnostic and research pathology. In:
Ueki H, Yaoita H, Eds. A colour atlas of dermatohistocytology. Tokyo: Wolfe Medical Publications Ltd; 1989. p. 31-42.

15. Boenish T. Staining methods. In: Naish Sj. Handbook: immunological staining methods. California: Dako cooperation; 1989. p. 13-23.

16. Farmilo AJ. Stead RH. Fixation in immunocytochemistry. In: Naish Sj. Handbook: immunological staining methods. California: Dako cooperation; 1989. p. 24-9.

17. Bos JD, Das PK, Kapsenberg ML. Skin immune system. In: Bos JD, Ed. Skin immune system. $1^{\text {sl }}$ ed. Boca Raton: CRP Press; 1990. p. 4-7.

18. Bos JD and Kapsenberg ML. Skin immune system: progress in cutaneous biology. Immunology to day 1993; $14: 75-8$

19. Boediardja SA. The role of immunogenetic factors of HLA in Prurigo Hebra. Disertation, Jakarta 1999. 


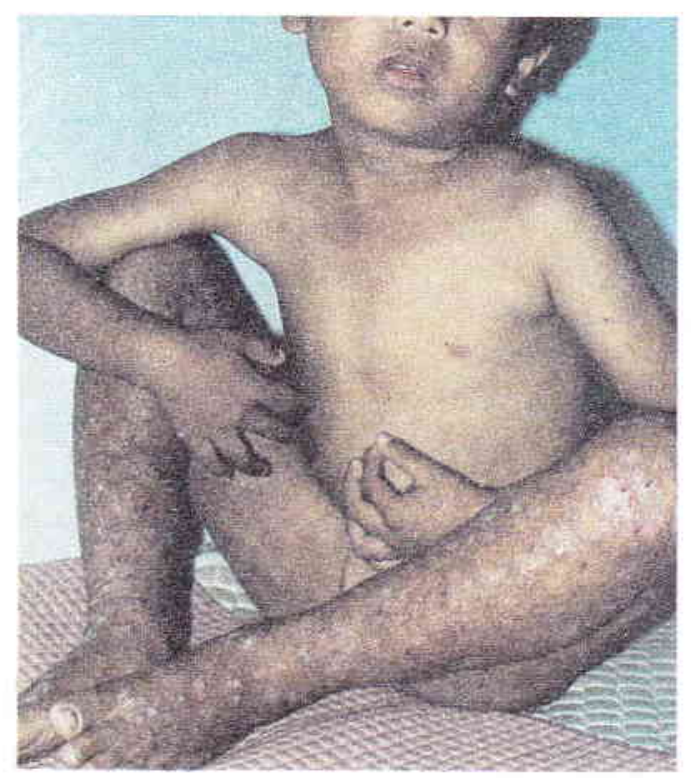

Figure 1. Prurigo Hebra in a child with severe condition, the skin lesions were seen on the extensor part of the ekstremities, but the body was spare.

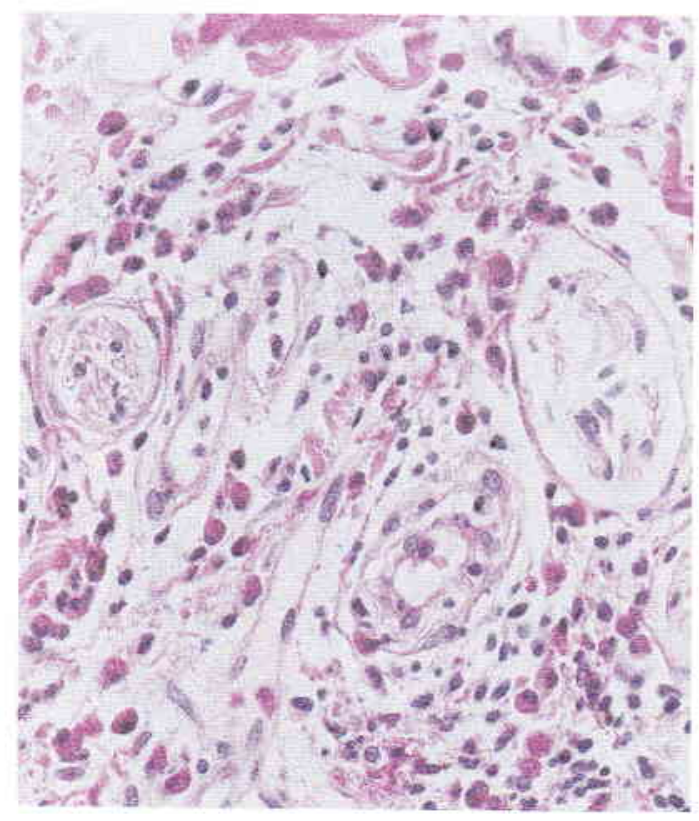

Figure 3. A mixed cells infiltration in early lesion of prurigo Hebra eosinophils were predominant than lymphocytes and hystiocytes ( $H E, 120 x)$.

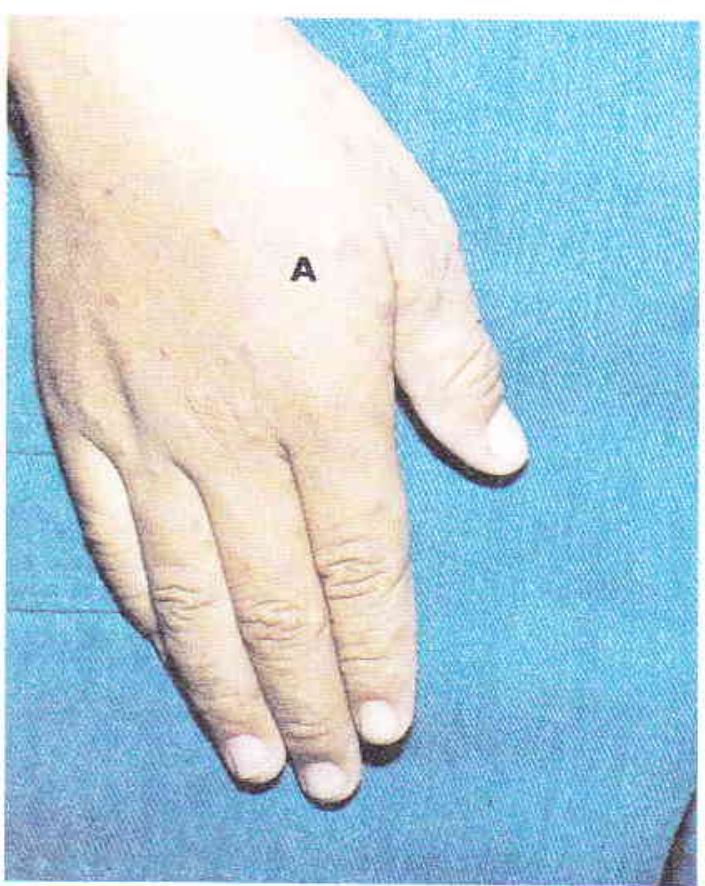

Figure 2. The characteristic of prurigo papules (dome shaped papules) were seen on the extensor part of the extremities

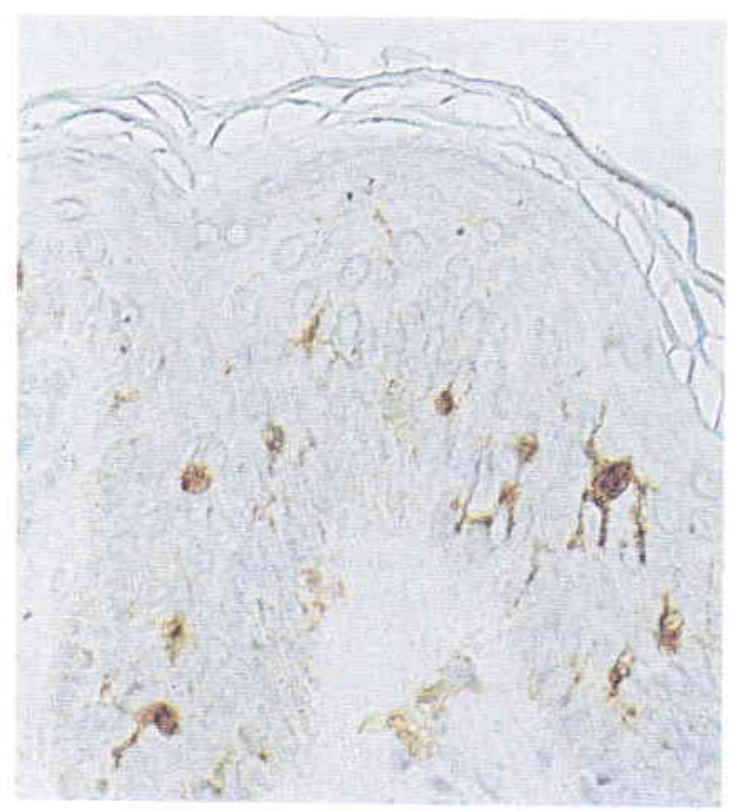

Figure 4. The expression of protein $S-100$ with $D A B$ chromogenic substrate, in the epidermal Langerhans cells (brownish in colour) of a prurigo Hebra patient (IP, 240x ). 


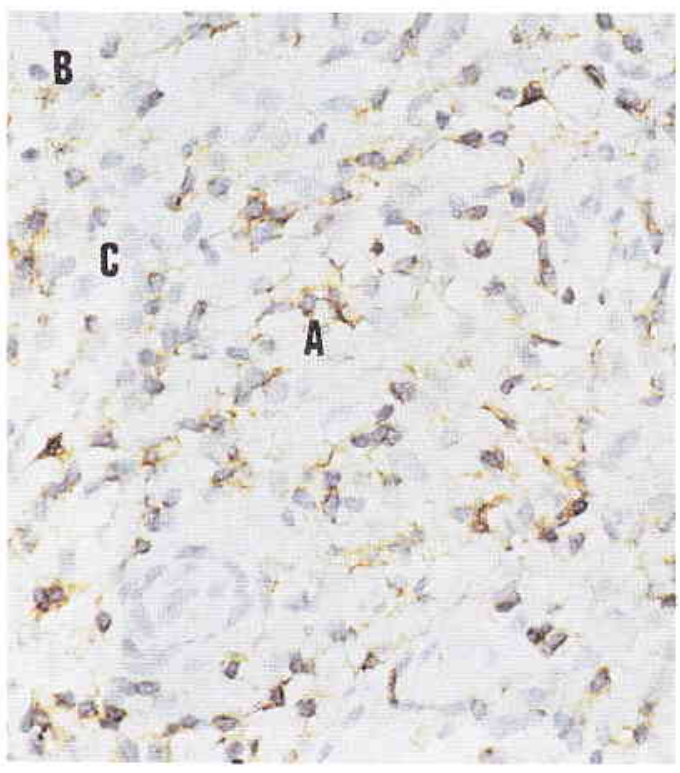

Figure 5. The expression of UHCL in T cells in an early lesion of cases No 19., were clearly seen (brownish in colour), within lymphocytes and histiocytes (IP, 120x).

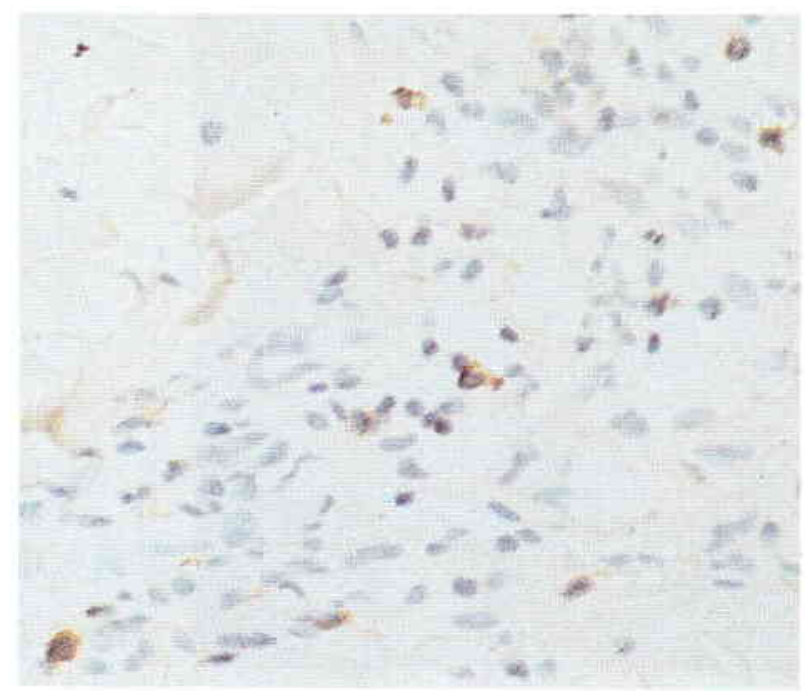

Figure 7. The expression of CD8+ monoclonal antibody in $C D 8+$ cells of an early lesion of cases No. 19., were less amount than CD4+ cells (IP, 120x).

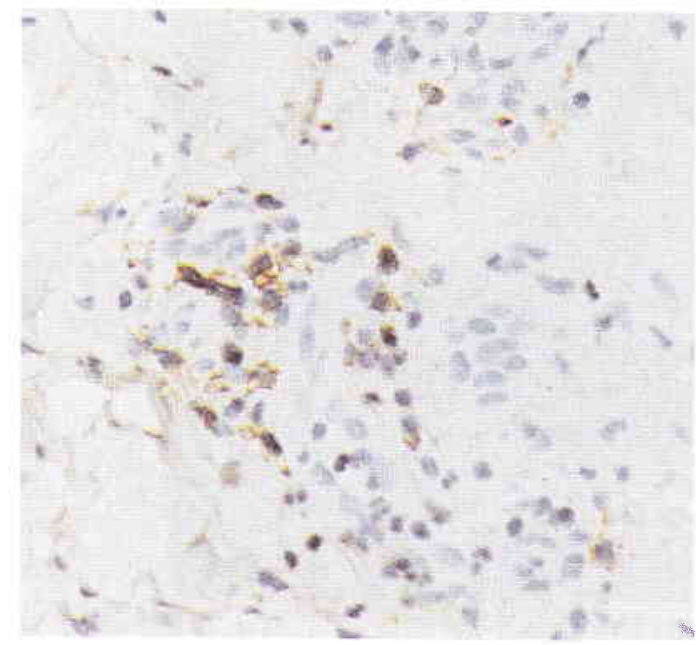

Figure 6. The expression of CD4+ monoclonal antibody in CD4+ cells of an early lesion of cases No.19., were seen less amount than T cells (IP, 120x).

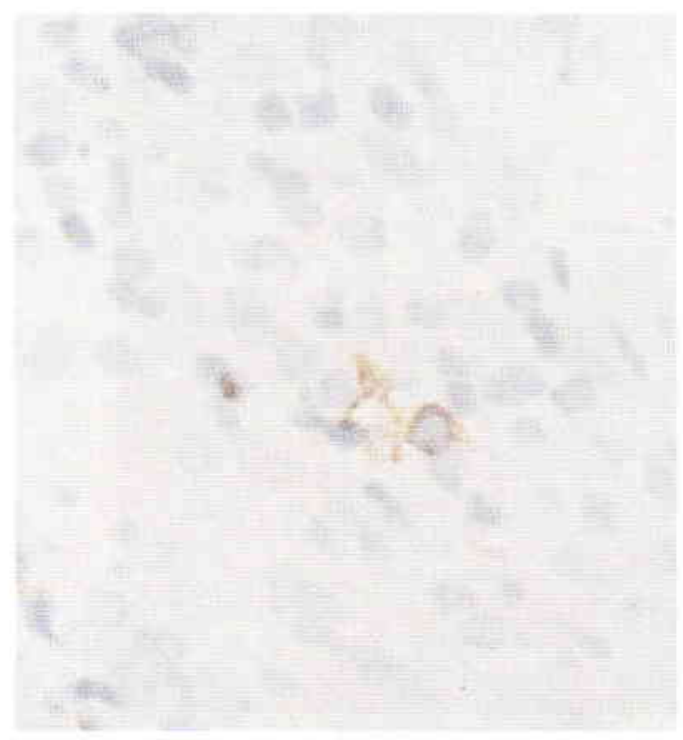

Figure 8. The expression of $L-26 / C D 20$ monoclonal antibody in $B$ cells of an early lesion of cases No.27, only one B cell was seen. (IP, 240x). 


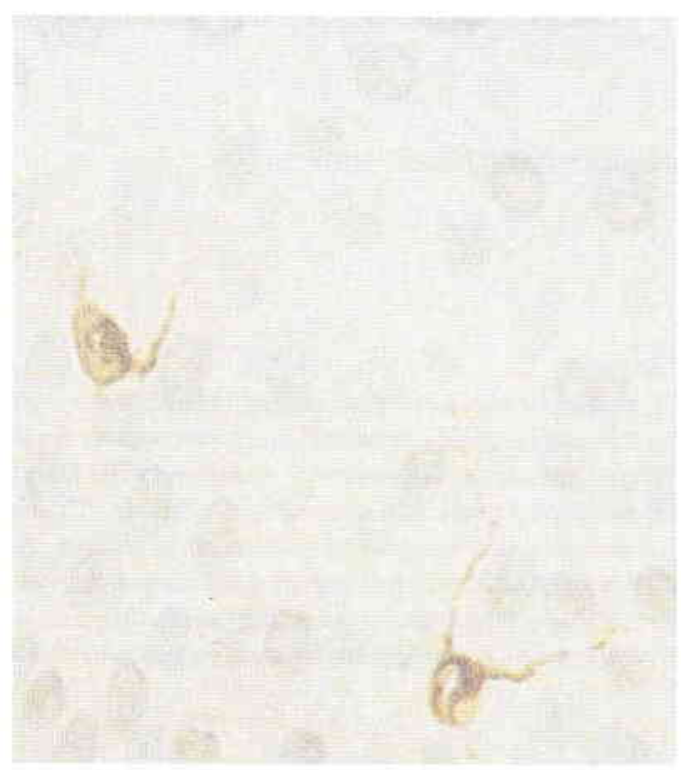

Figure 9. The expression of $H L A-D R \alpha$ monoclonal antibody in dermal antigen presenting cells (APC) (brownish in colour) of an early lesion of prurigo Hebra. The interaction between lymphocytes and $A P C$ was seen $(I P, 240 x)$

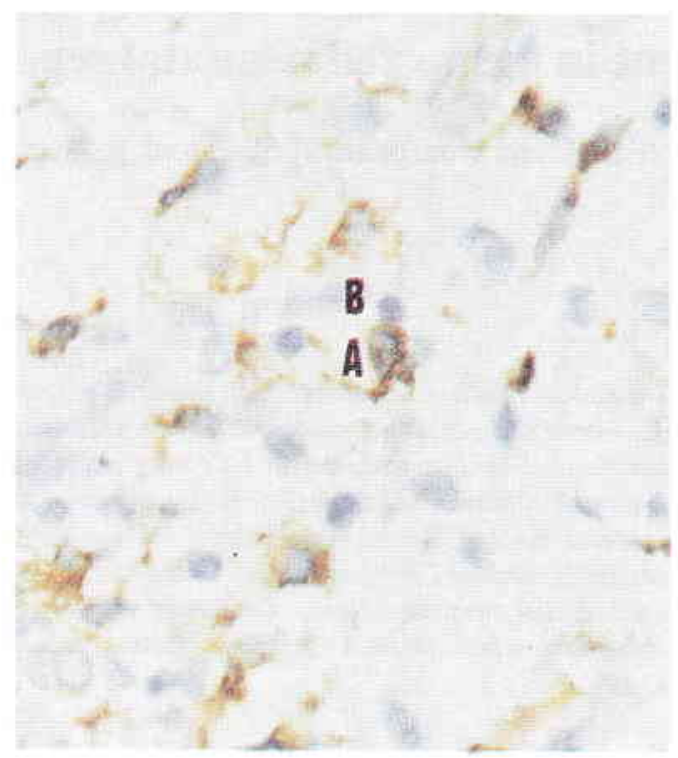

Figure 10. The expression of HLA-DR $\beta$ monoclonal antibody in dermal antigen presenting cells (APC) (brownish in colour) of an early lesion of prurigo Hebra. The interaction between lymphocytes and $A P C$ was seen (IP, 240x) 